\title{
Acid-induced Death in Neurons and Glia
}

\author{
Maiken Nedergaard, Steven A. Goldman, Smita Desai, and William A. Pulsinelli \\ Department of Neurology and Neuroscience, Raymond and Beverly Sackler Foundation, Cornell University Medical \\ College, New York, New York 10021
}

\begin{abstract}
Lactic acidosis has been proposed to be one factor promoting cell death following cerebral ischemia. We have previously demonstrated that cultured neurons and glia are killed by relatively brief (10 $\mathrm{min}$ ) exposure to acidic solutions of pH $<5$ (Goldman et al., 1989). In the present series of experiments, we investigated the relationship between changes in intracellular $\mathrm{pH}\left(\mathrm{pH}_{i}\right)$ and cellular viability. $\mathrm{pH}_{i}$ was measured using fluorescent $\mathrm{pH}$ probes and was manipulated by changing extracellular $\mathrm{pH}\left(\mathrm{pH}_{\mathrm{e}}\right)$. Homeostatic mechanisms regulating $\mathrm{pH}_{i}$ in neurons and glia were quickly overwhelmed: neither neurons nor glial cells were able to maintain baseline

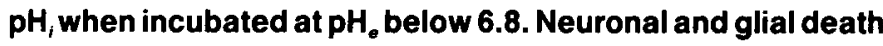
was a function of both the degree and the duration of intracellular acidification, such that the $\mathbf{L D}_{50}$ following timed exposure to $\mathrm{HCl}$ increased from $\mathrm{pH}_{i} 3.5$ for 10 -min acid incubations to $\mathrm{pH}_{i} 5.9$ for 2-hr exposures and $\mathrm{pH}_{i} 6.5$ for $6-\mathrm{hr}$ exposures.
\end{abstract}

Replacement of $\mathrm{HCl}$ with lactic acid raised the $\mathrm{LD}_{50}$ to $\mathrm{pH}_{i}$ 4.5 for $10-\mathrm{min}$ acid exposures, but did not change the $L_{50}$

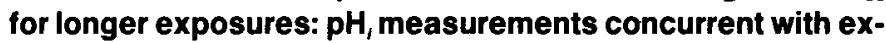
tracellular acidification suggested that the greater cytotoxicity of lactic acid relative to that of $\mathrm{HCl}$ was caused by the more rapid intracellular acidification associated with lactic acid. The onset of death after exposure to moderately acidic solutions was delayed in some cells, such that death of the entire cell population became evident only $48 \mathrm{hr}$ after acid exposure. During this latency period, cellular viability indices and ATP levels fell in parallel. The course of death could be experimentally manipulated: hypothermia initiated after the acid exposure attenuated the degree of cell death, indicating that processes occurring during this postinjury period were responsible for demise. Thus, a delayed process of cell death can be initiated in vitro by an initial insult other than glutamate exposure, and this process can occur in glia as well as in neurons.

Cerebral hypoxia-ischemia induces lactic acid formation through the accentuation of anaerobic glycolysis. The magnitude of this lactic acid accumulation depends largely upon the preischemic

\footnotetext{
Received Nov. 29, 1990; revised Mar. 26, 1991; accepted Mar. 27, 1991

We thank Dr. Martin Lesser for his assistance with the statistical analysis of these data. This research was supported in part by Kobmand i Odense Johann and Hanne Weimann, f. Seedorffs legat, by NIH Grant NS-03346, by National Institute of Neural Disorders and Stroke Grant NS-01316, and by grants from the G. Harold and Leila Y. Mathers Charitable Foundation and from Mr. and Mrs. Fowler Merle-Smith. S.A.G. is a Cornell Scholar in Biomedical Science.

Correspondence should be addressed to Dr. M. Nedergaard, Department of Neurology and Neuroscience, Cornell University Medical College, 1300 York Avenue, New York, NY 10021.

Copyright (C) 1991 Society for Neuroscience 0270-6474/91/112489-09\$03.00/0
}

glucose and glycogen concentrations of the affected tissue (Smith et al., 1986). I ocal accumulation of lactic acid to cytotoxic levels may play a causal role in the genesis of brain infarction following cerebral ischemia (Meyer and Yamaguchi, 1977; Siemkowitz and Hansen, 1978; Pulsinelli et al., 1982; Nedergaard, 1987).

Several authors have addressed directly the issue of acidinduced cell death. Cultured neurons and astrocytes die following relatively brief exposures to extracellular $\mathrm{pH}\left(\mathrm{pH}_{e}\right)$ below 5.3 (Norenberg et al., 1987; Goldman et al., 1989). In vivo, exposure of rat parietal cortex to lactic acid below $\mathrm{pH}_{c} 5.3$ for 20 min caused frank brain infarction (Kraig et al., 1987). However, such extremes of tissue $\mathrm{pH}$ may not be encountered during in vivo global or focal ischemia, unless the animals are exposed to marked degrees of preischemic hyperglycemia (Kraig and Chesler, 1990). Rather, tissue pH may be moderately lowered for many hours in those areas of focal ischemia that ultimately necrose (Kobatake et al., 1984; Nedergaard et al., 1990). This article examines the possibility that the prolongation of acid exposure does in fact lower the threshold for acid-induced cell death, thereby providing a mechanism by which brain tissue might infarct at $\mathrm{pH}$ levels within the range achieved in vivo during ischemic acidosis.

To test this hypothesis, neurons and glial cells were loaded with $\mathrm{pH}$-sensitive dyes and exposed to extracellular acid for periods ranging from $10 \mathrm{~min}$ to several hours. Neuronal and glial intracellular $\mathrm{pH}\left(\mathrm{pH}_{i}\right)$ was determined by microspectrofluorometry and was correlated with cell viability, as assessed by trypan blue exclusion. The results indicate that the cellular $\mathrm{LD}_{\text {so }}$ for $\mathrm{H}^{+}$ions is an inverse function of the duration of acid exposure.

\section{Materials and Methods}

Tissue dissociation and culture. Mixed forebrain cultures were derived from 16-d-gestation rat embryos and prepared as previously described (Goldman et al., 1989); $10^{6}$ cells were plated in each of 24 wells in polyL-lysine treated plates (Falcon). For pH, measurements, $2 \times 10^{\circ}$ cells were plated on poly-L-lysine coated $25-\mathrm{mm}$ round coverslips maintained in $35-\mathrm{mm}$ Corning dishes. The cultures were kept at $37^{\circ} \mathrm{C}$ in $5 \% \mathrm{CO}_{2}$ humidified air. Cultures were exposed to acid after $8-10 \mathrm{~d}$ in vitro(DIV), unless otherwise stated.

Culture medium. The culture medium consisted of $20 \%$ fetal calf serum and $80 \%$ Dulbecco's modified Eagle's medium, supplemented with $4 \mathrm{mM}$ L-glutamine, $100 \mu \mathrm{M}$ nonessential amino acids, $8 \mathrm{mg} / \mathrm{ml}$ D-glucose, $5 \mu \mathrm{g} / \mathrm{ml}$ insulin, $20 \mathrm{U} / \mathrm{ml}$ penicillin-G, $20 \mu \mathrm{g} / \mathrm{ml}$ streptomycin, and $50 \mathrm{ng} / \mathrm{ml}$ amphotericin. Half-volume media changes were performed every third day.

Acid exposure. Following an 8-10-d incubation period, test cultures were exposed to HEPES-buffered Ringer's solution (HBS), titrated with $\mathrm{HCl}$ to a pH within the range of 2.2-7.3. Each culture was washed three times in the appropriate acidified HBS, then exposed to the test solutions from 10 to $360 \mathrm{~min}$ in a $\mathrm{CO}_{2}$-free incubator at $37^{\circ} \mathrm{C}$. The test solutions were changed every $2 \mathrm{hr}$ during those acid exposures exceeding 120 
min. Following acid exposure, each culture was washed once in fresh medium and left for $24 \mathrm{hr}$ in the incubator before viability counting, unless otherwise indicated. The HEPES-buffered solution was composed of $150 \mathrm{mM} \mathrm{NaCl}, 1 \mathrm{~mm} \mathrm{MgSO}, 1 \mathrm{mM} \mathrm{K}_{2} \mathrm{HPO}_{4}, 20 \mathrm{~mm} \operatorname{HEPES}(N-2-$ hydroxyethylpiperazine- $N$-2-ethenesulfonic acid), $10 \mathrm{~mm}$ glucose, and $1.5 \mathrm{mM} \mathrm{CaCl}_{2}$. In some experiments, $20 \mathrm{~mm}$ sodium L-lactate was substituted for $20 \mathrm{~mm} \mathrm{NaCl}$. Solutions containing $\mathrm{CO}_{2}$ were bubbled with $5 \% \mathrm{CO}_{2} / 95 \%$ air for 30 min before titration with $\mathrm{HCl}$. Extracellular $\mathrm{pH}$ was determined with an electronic $\mathrm{pH}$ meter (Beckman Instruments, model 55), in combination with a Microelectrodes MI-410 pH probe. Both were reliable to $0.01 \mathrm{pH}$ unit. All $\mathrm{pH}$ measurements were made at $37^{\circ} \mathrm{C}$.

Hypothermia. The effect of lowered incubation temperatures upon acid-induced injury was examined by lowering the ambient incubation chamber temperature to $32^{\circ} \mathrm{C}$ after acid exposure at $37^{\circ} \mathrm{C}$. After the exposure, one set of cultures was kept in this incubator for $4 \mathrm{hr}$ and then transferred to an incubator at $37^{\circ} \mathrm{C}$

Viability criteria and index. Loss of membrane integrity, as determined by trypan blue inclusion, was used as a marker of cell death (Phillips, 1969; Choi et al., 1987; Goldman et al., 1989). A total of 496 cultures were exposed to acidified solutions, spanning a wide range of $\mathrm{pH}_{e}$ and exposure duration, as noted above. After appropriate postexposure survival times, the cells, both adherent and detached, were counted by hemocytometer, following $15 \mathrm{~min}$ incubation in trypan blue as previously described (Goldman et al., 1989). Neurons and glia were pooled for this determination, as no effort was made to assess their differential sensitivities to acidosis.

In a separate experiment, lactate dehydrogenase $(\mathrm{LDH})$ release into the culture medium was correlated to trypan blue-stained cells in the same cultures. LDH activity was measured spectrophotometrically (Schnaar et al., 1987). The percentage cell death was defined as the amount of LDH released into the culture medium, divided by LDH activity in lysed sister cultures. The lysis buffer used for the latter cultures was composed of $1 \mathrm{ml}$ of $0.1 \mathrm{M}$ phosphate buffer containing $1 \%$ Triton $\mathrm{X}-100$.

Metabolic measurements. ATP concentrations were measured by the enzyme-fluorometric method described by Lowry and Passonneau (1972) and expressed as $\mu \mathrm{mol} / \mathrm{gm}$ protein. Briefly, $0.1 \mathrm{ml}$ of ice-cold $3 \mathrm{M}$ perchloric acid was added to each well for $15 \mathrm{~min}$, then diluted with $20 \mu \mathrm{l}$ of $8 \mathrm{M}$ EDTA. The mixtures were removed from the dish and centrifuged at $5000 \times g$ for $10 \mathrm{~min}$, and the supernate was neutralized to $\mathrm{pH} 6.8-$ 7.0 with a mixture of $2 \mathrm{M} \mathrm{KOH}, 0.4 \mathrm{M}$ imidazole, and $0.4 \mathrm{M} \mathrm{KCl}$. The mixtures were centrifuged at $5000 \times g$ for $10 \mathrm{~min}$, and the supernates were stored at $-80^{\circ} \mathrm{C}$ until analyzed. Protein content was measured in sister cultures using the Bio-Rad Coomasie-based protein assay, with a bovine serum albumin standard. Protein was collected by applying 0.4 $\mathrm{ml}$ of boiling distilled water to each cell well; the contents were then suctioned off and boiled for $5 \mathrm{~min}$ before frozen storage and measurement.

Immunocytochemistry. Immunocytochemical stains for glial fibrillar acidic protein (GFAP; Sigma clone GA-5) and neurofilament protein (Sigma clone NN-18) or microtubule-associated protein (MAP-2; Sigma clone HM-2) were used to identify astrocytes and neurons, respectively. Procedures were as previously described (Goldman, 1989). In selected experiments, phase-contrast photomicrographs were taken immediately after $\mathrm{pH}$ measurement and were used to reidentify the measured cells following immunohistochemistry.

Intracellular $\mathrm{pH}$ measurements. Cytosolic $\mathrm{pH}$ was determined in a total of 79 cultures, by microspectrofluorometry of cells loaded with $\mathrm{pH}$-sensitive fluorescent dyes. These dyes are esterified compounds, which are all membrane permeable. Once gaining cellular entry, the dye esters are hydrolyzed by cytosolic esterases to membrane-impermeant ions (Rink et al., 1982). Three dyes were used in this study (Molecular Probes), each employed over its effective $\mathrm{pH}$ range, as determined by its $\mathrm{p} K_{a}$ : BCECF $\left(2^{\prime}, 7^{\prime}\right.$-bis-[2-carboxyethyl]-5-[and-6] carboxyfluorescein), DCF (5-[and-6]-carboxyfluorescein), and CDCF (5-[and-6]-carboxy-2',7-dichlorofluorescein). BCECF has a $\mathrm{p} K_{a}$ of 7.0 (Rink et al., 1982); DCF, a $\mathrm{p} K_{a}$ of 6.4 (Thomas, 1986); and CDCF, a $\mathrm{p} K_{a}$ of 4.2 (Nedergaard et al., 1990). The cells were dye loaded by incubation in either $5 \mu \mathrm{M}$ BCECF acetoxymethyl ester (AM) for $15 \mathrm{~min}, 1 \mu \mathrm{M}$ of DCF $\mathrm{AM}$ for $10 \mathrm{~min}$, or $1 \mu \mathrm{M} C D C F$ diacetate for $10 \mathrm{~min}$, all at $37^{\circ} \mathrm{C}$. Following dye incubation, the culture-bearing coverslips were washed in HBS and mounted in a Leiden chamber maintained at $37^{\circ} \mathrm{C}$ by a TC-102 temperature controller (Medical System Corp.). All changes of solutions bathing the cultures were done by injection through a syringe, and excess medium was aspirated; complete solution exchange was accomplished in less than $5 \mathrm{sec}$. All measurements of $\mathrm{pH}_{i}$ were made in HBS. Intracellular $\mathrm{pH}$ calibration standards for individual cells were established by exposing the cultures, after measurement, to a potassium Ringer's solution containing $10 \mu \mathrm{M}$ of the ionophore nigericin. Nigericin in combination with high potassium equalizes extracellular and intracellular $\mathrm{pH}$ (Chaillet and Boron, 1985). The potassium Ringer's solution employed consisted of $70 \mathrm{mM} \mathrm{KCl}, 10 \mathrm{~mm}$ glucose, $1 \mathrm{~mm} \mathrm{CaCl}, 2.5$ $\mathrm{mm} \mathrm{K}_{2} \mathrm{HPO}_{4}, 10 \mathrm{~mm}$ IIEPES, $1 \mathrm{~mm} \mathrm{MgSO}_{4}$, and $90 \mathrm{~mm}$ sucrose.

Fluorescence from individual neurons and glia, as well as from small cellular aggregations, was monitored by a microspectrofluorometer. Measurements were obtained from a 10- $\mu \mathrm{m}$-diameter field with an adjustable field aperture placed in front of the photomultiplier tube. In all measurements of neurons, we focused upon the cell body. As a result of poor dye uptake among glia, relative to their neuronal counterparts (Connor et al., 1987), as well as to the thin, well-spread topography of cultured astrocytes, the contamination of neuronal signal by glial counts was low. Also, we attempted to measure neurons positioned in areas free of underlying glia. Monochromatic excitation was accomplished using a Photon Technology Delta Scan, in which a xenon arc beam is split by a rotating chopper into two beams, each of which passes through a narrow-range monochromotor (4-nm band width), which permits precise wavelength selection. In this study, dual excitation at $495 \mathrm{~nm}(\mathrm{pH}$ sensitive) and $440 \mathrm{~nm}$ ( $\mathrm{pH}$ insensitive) was used for both BCECF and CDCF, while DCF was excited at $487 \mathrm{~nm}$ (pH sensitive) and $450 \mathrm{~nm}$ (pH insensitive). The Delta Scan was attached to a Leitz Diavert microscope equipped with a Nikon $40 \times 1.3$-NA Fluor objective. Emissions of $>510 \mathrm{~nm}$ were measured for each excitation wavelength, for $4.5 \mathrm{msec}$ of every $10-\mathrm{msec}$ cycle. The ratio of emission intensities at the 495- and 440-nm excitation wavelength was then calculated (the 495:440 ratio); these measurements were integrated over 1 sec and stored in an NEC 386 Powermate computer. Intracellular $\mathrm{pH}$ was then calculated by the formula

$$
\left.\mathrm{pH}=\mathrm{p} K_{a}+\log \left(\left(R-R_{\min }\right) / R_{\max }-R\right)\right),
$$

where $R$ is the ratio measured at the given $\mathrm{pH}$, and $R_{\min }$ and $R_{\max }$ are the limiting values of this ratio at the extremes of acid and alkaline $\mathrm{pH}$ respectively. For CDCF, $R_{\max }=8.4$ and $R_{\min }=2.7$. CDCF was used in the $\mathrm{pH}$ range 3.5-5.3. DCF was used in the $\mathrm{pH}$ range 5.4-6.4, and $B C E C F$ was used in the $\mathrm{pH}$ range 6.5-7.3; within these respective ranges, the relation between $R$ and $\mathrm{pH}$ is linear, thus allowing a simple transformation of the signal-intensity ratio into $\mathrm{pH}$.

Statistical analysis. All results are expressed as the mean \pm SD. Oneway analysis of variance (ANOVA) was used to compare mean values of ATP content and viability index among groups (see Fig. 5), while Tukey's multiple range test was used to determine which groups significantly differed from control values. Two-tailed Student's $t$ test was used to analyze differences among paired groups in Tables 2 and $3 . \mathrm{LD}_{50}$ was determined using probit analysis, in which the percentage of cells killed was transformed according to a probit transformation. Probit was regressed on $\mathrm{pH}$, and $\mathrm{LD}_{\mathrm{s}}$ was estimated by inverting the regression equation at probit $=0$. Observations with percent killed $=0$ or 100 were assigned probits of -5 and +5 , respectively.

\section{Results}

Comparison among viability determination methods. $\mathrm{LDH}$ release to the culture medium $24 \mathrm{hr}$ following acid exposure $(\mathrm{pH}$ 4.1-7.3) was compared to the viability index determined by trypan blue uptake in 56 cultures in a separate experiment (Fig. 1). A high correlation ( $r=0.92)$ was found between these independent modalities of viability assessment.

Cellular viability following $10-\mathrm{min} \mathrm{HCl}$ exposure. Twentyfour hours following acid exposure, cultures exposed to $\mathrm{HCl}$ at $\mathrm{pH}_{e} 3.5$ and above retained normal morphology and excluded trypan blue (Fig. $2 A$ ). In contrast, cells exposed to $\mathrm{pH}_{e}$ below 3.1 underwent process retraction and somal rounding, with detachment from their substrate and trypan blue inclusion. Probit analysis of cellular viability yielded an $\mathrm{LD}_{50}$ for $\mathrm{HCl}$ of $\mathrm{pH}_{r} 3.3$.

Cellular viability following $10-$ min lactic acid exposure. HBS solutions containing $20 \mathrm{~mm}$ lactic acid were titrated over a pH range of 4.0-7.3 The cells were exposed for $10 \mathrm{~min}$ to the test 


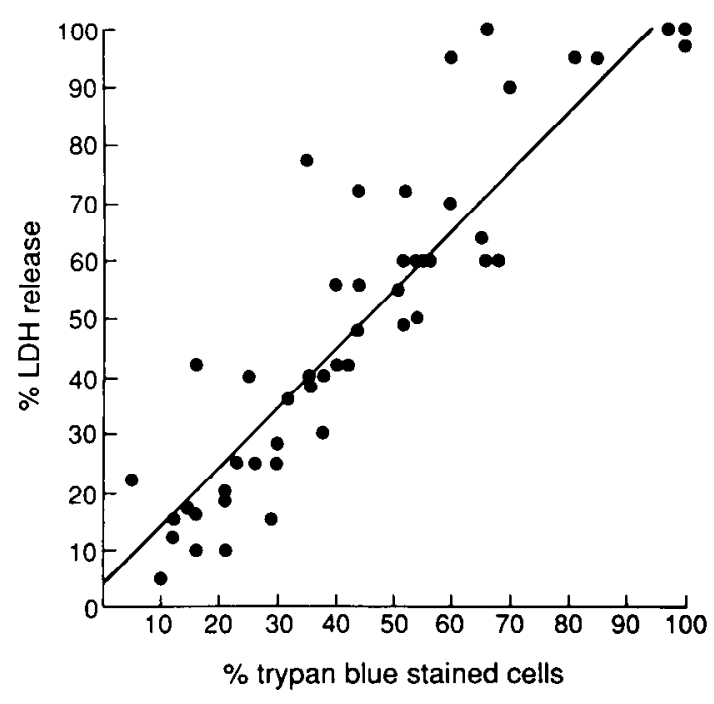

Figure 1. Validation of viability index. Cellular death as used in this article is indicated at the $x$-axis and is defined as the percentage of cells stained with trypan blue $24 \mathrm{hr}$ after the exposure. $\mathrm{LDH}$ release to the culture medium is indicated at the $y$-axis. \% $L D H$ release was defined as LDH activity in culture medium divided by $\mathrm{LDH}$ activity from lysed sister cultures. The regression line of LDH release as a function of trypan blue-stained cells described $y=3.96+1.02 x ; r=0.92$.

acid solution. Virtually all cells exposed for $10 \mathrm{~min}$ to $\mathrm{pH}_{e} 4.4$ or below incorporated trypan blue when stained $24 \mathrm{hr}$ following exposure (Fig. $2 B$ ). In contrast, most cells survived such exposure to $\mathrm{pH}_{e}$ over 4.8 (Fig. 3). Probit analysis yielded an $\mathrm{LD}_{50}$ for lactic acid of $\mathrm{pH}_{e} 4.6$.

Cellular viability following 10 -min exposure to acidified culture media. Exposure to $\mathrm{HCl}$-acidified culture media, rather than acidified HBS, raised the $\mathrm{LD}_{50}$ from $\mathrm{pH}_{e} 3.3$ to $4.1(n=32)$. Addition of $20 \mathrm{~mm}$ lactate to the culture medium increased the threshold from $\mathrm{pH}_{e} 4.6$ to $4.9(n=27)$. $^{\prime}$

\footnotetext{
'These data confirm an earlier report (Goldman et al., 1989) in which culture medium was used as the vehicle for acid exposure, rather than the HBS used in the present study. Unlike $\mathrm{HBS}$, the culture medium is buffered with $\mathrm{HCO}_{3}{ }^{-} / \mathrm{CO}_{2}$. $\mathrm{CO}_{2}$ is a highly membrane-permeable weak acid, capable of mediating rapid intracellular acidification (Roos and Boron, 1981). Thus, the cellular $L^{2} D_{50}$ s for acid injury were found to be at higher $\mathrm{pH}$ levels (lower acid concentrations) in bicarbonate-buffered media than in HBS.
}

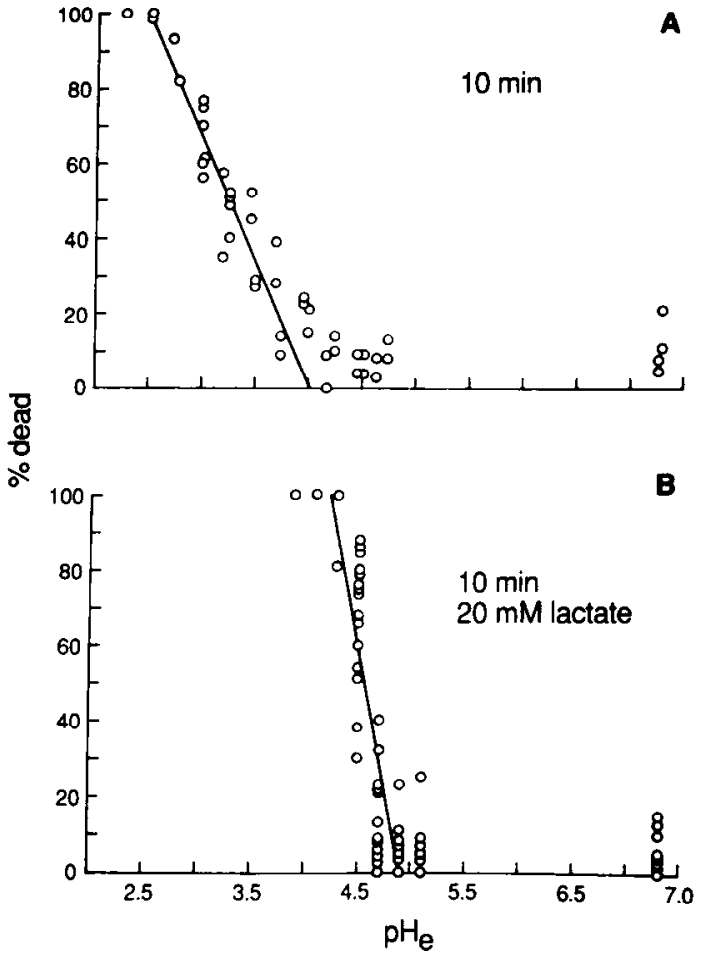

Figure 2. Determination of threshold for acid-induced cell death. The cultures were exposed for 10 min to HBS titrated to the $\mathrm{pH}$ levels noted on the abscissa. Cellular death is indicated on the $y$-axis and is defined as the percentage of cells stained with trypan blue $24 \mathrm{hr}$ after exposure. Neurons and glial cells were pooled for this determination. $A$, HBS titrated with $\mathrm{HCl}: \mathrm{LD}_{50}=\mathrm{pH}$ 3.3. $B$, Lactate $(20 \mathrm{~mm})$ added to the HBS titrated with $\mathrm{HCl}: \mathrm{LD}_{30}=\mathrm{pH} 4.6$.

Intracellular acidification by extracellular $\mathrm{HCl}$. Using $\mathrm{CDCF}$, $\mathrm{pH}_{i}$ was measured in single neurons and glial cells. Exposure to $\mathrm{HCl}$ in $\mathrm{HBS}$ at the $\mathrm{LD}_{50}$ of $\mathrm{pH}_{e} 3.3$ induced a slow, steady decline of $\mathrm{pH}_{i}$, which reached $3.52 \pm 0.18(n=5)$ in neurons and 3.53 $\pm 0.33(n=4)$ in glia by the end of the 10 -min acid exposure (Fig. $4 A$, Table 1 ). $\mathrm{pH}_{i}$ rapidly normalized when the acidified HBS solution was replaced by one with a normal pH (7.3).

Intracellular acidification by extracellular lactic acid. Exposure of cells to HBS containing lactate at its threshold $\left(\mathrm{LD}_{50}\right)$

\section{Table 1. $\mathrm{pH}_{i}$ during acid exposure}

\begin{tabular}{|c|c|c|c|}
\hline \multirow{2}{*}{$\begin{array}{l}\text { Exposure } \\
\text { time }\end{array}$} & \multirow[b]{2}{*}{$\mathrm{pH}_{e}$} & \multicolumn{2}{|l|}{$\mathrm{pH}_{i}$} \\
\hline & & Neurons & Glia \\
\hline \multicolumn{4}{|l|}{$10 \mathrm{~min}$} \\
\hline Without lactate & 3.3 & $3.52 \pm 0.18(5)$ & $3.53 \pm 0.33(4)$ \\
\hline With lactate & 4.6 & $4.48 \pm 0.12(10)$ & $4.48 \pm 0.10(4)$ \\
\hline \multicolumn{4}{|l|}{$2 \mathrm{hr}$} \\
\hline Without lactate & 5.4 & $5.58 \pm 0.04(9)$ & $5.64 \pm 0.05(8)$ \\
\hline Without lactate & 5.6 & $5.87 \pm 0.05(9)$ & $5.90 \pm 0.02(12)$ \\
\hline With lactate & 5.6 & $5.87 \pm 0.08(12)$ & $5.93 \pm 0.09(12)$ \\
\hline Without lactate & 6.0 & $6.12 \pm 0.08(11)$ & $6.02 \pm 0.06(9)$ \\
\hline $4 \mathrm{hr}$, without lactate & 6.1 & $6.01 \pm 0.06(11)$ & $6.10 \pm 0.15(17)$ \\
\hline $6 \mathrm{hr}$, without lactate & 6.4 & $6.46 \pm 0.09(15)$ & $6.40 \pm 0.11(14)$ \\
\hline
\end{tabular}



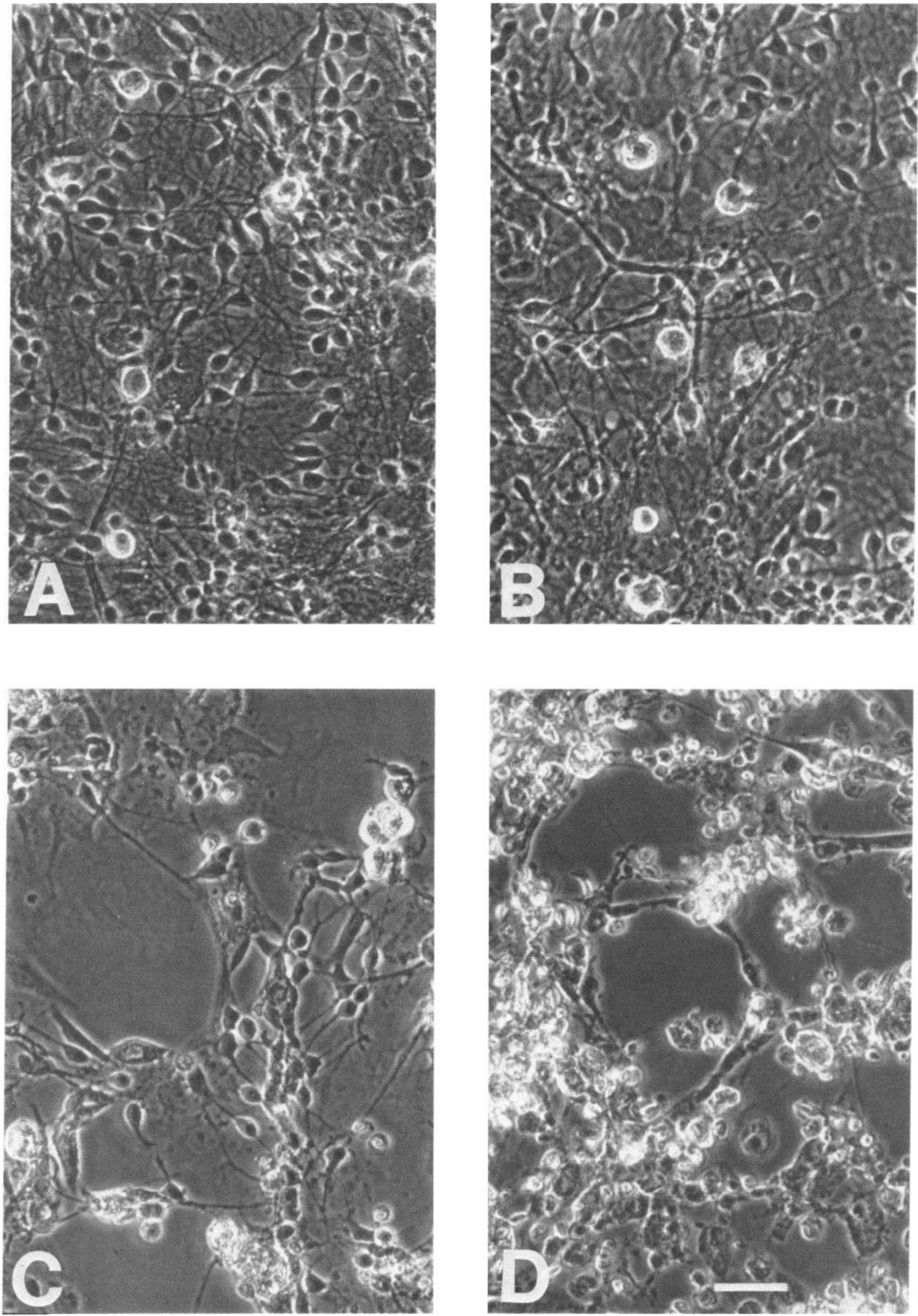


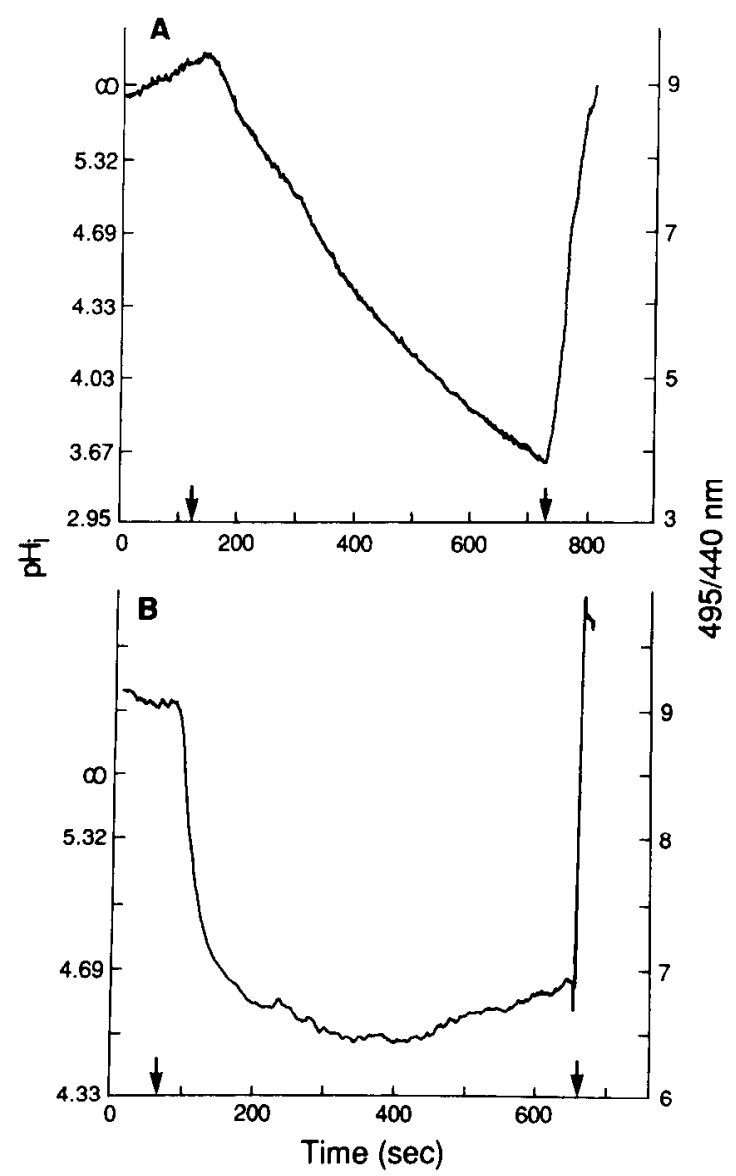

Figure 4. $\mathrm{pH}_{i}$ during acid exposure. $A$, Ten minutes exposure to $\mathrm{pH}$ $3.3 \mathrm{HCl}$ in $\mathrm{HBS}$ in an astrocyte. $\mathrm{pH}_{i}$ declines slowly to 3.5 and returns quickly to baseline $\mathrm{pH}$ upon normalizing $\mathrm{pI}_{e}$ to 7.3. $\mathrm{B}$. Neuron exposed to $\mathrm{pH} 4.6$ in an $\mathrm{HBS}$ containing $20 \mathrm{~mm}$ lactate. The cell rapidly acidifies to $\mathrm{pH} 4.45$. CDCF, with a $\mathrm{pK}_{a}$ of 4.2 , was used as the $\mathrm{pH}$ probe in these experiments.

$\mathrm{pH}_{i}$ of 4.6 induced a rapid intracellular acidification. $\mathrm{pH}_{i}$ stabilized at $4.6 \pm 0.21$ after $2 \mathrm{~min}$ in both neurons (Fig. $4 B$ ) and

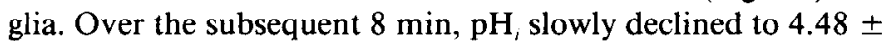
0.12 in neurons $(n=10)$ and $4.48 \pm 0.10$ in glia $(n=4) . \mathrm{pH}_{i}$ quickly returned to baseline upon normalizing $\mathrm{pH}_{e}$. Thus, $\mathrm{pH}_{i}$ declined to levels of roughly 4.5 and 3.5 following cellular exposure to HBS solutions titrated to $\mathrm{pH}_{e} 4.6$ and 3.3. These points represent the $\mathrm{LD}_{s 0} \mathrm{pH}_{e}$ values for 10 -min exposure to lactic acid and $\mathrm{HCl}$, respectively.

The apparent difference between the $\mathrm{LD}_{50}$ for $\mathrm{HCl}$ and lactic acid solutions may reflect the more rapid intracellular acidification achieved by lactic acid, and therefore the longer duration of toxic intracellular acidosis.

Cellular viability following 2-6 $\mathrm{hr}$ acid exposure. In order to test the possibility that acid-induced death might be a function of both the degree and the duration of intracellular acidification, viability was assessed among cells exposed to acidified solutions, at various $\mathrm{pH}$ levels and for varying durations of time including
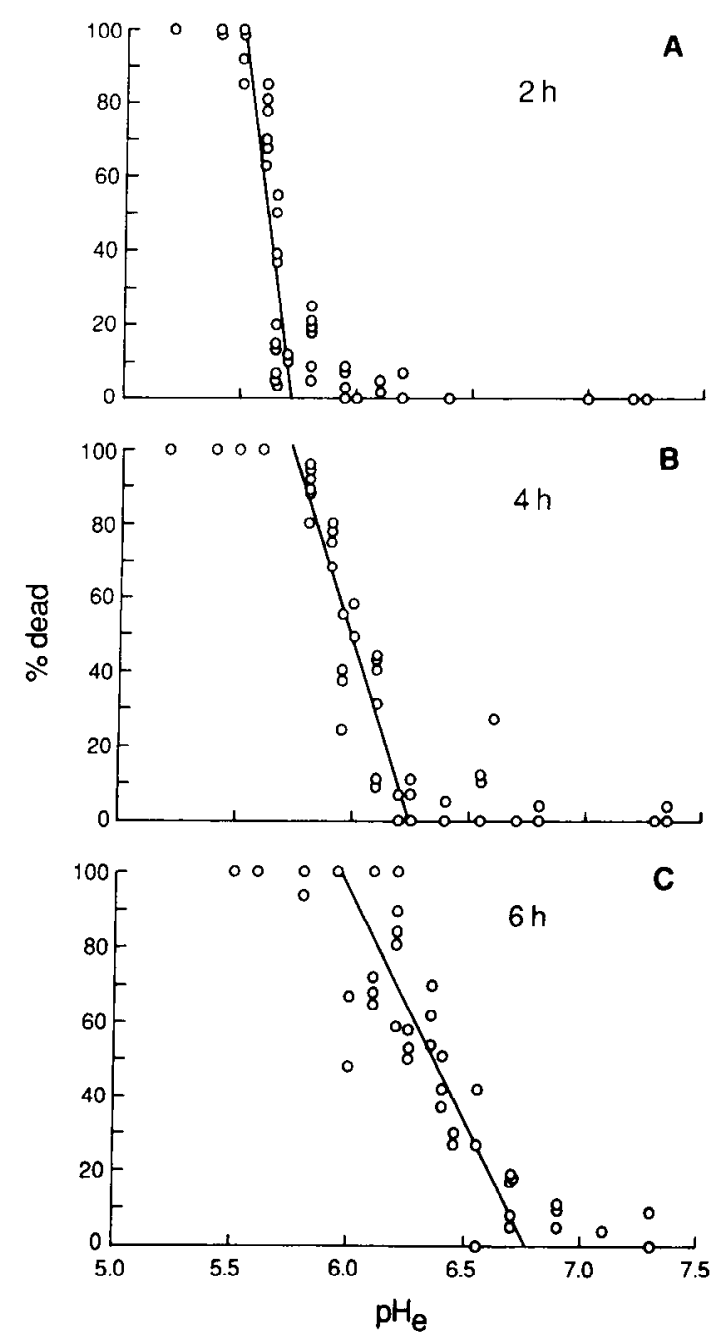

Figure 5. Determination of thresholds for acid-induced cell death. Cellular death is indicated on the $y$-axis and is defined as the percentage of cells stained with trypan blue. The cultures were exposed to HBS titrated to the $\mathrm{pH}$ levels noted on the abscissa. $A, \mathrm{LD}_{\mathrm{s} 0}=\mathrm{pH} 5.6 ; 2-\mathrm{hr}$ exposure. $B, \mathrm{LD}_{50}=\mathrm{pH} 6.1 ; 4-\mathrm{hr}$ exposure. $C, \mathrm{LD}_{50}=\mathrm{pH} 6.4 ; 6-\mathrm{hr}$ exposure.

2,4 , and $6 \mathrm{hr}$, and examined for cell survival $24 \mathrm{hr}$ later. Figure $5 A-C$ illustrates cellular viability among cultures assessed $24 \mathrm{hr}$ after acid exposure: $\mathrm{LD}_{50}$ varied as a function of the time and degree of acid exposure, such that $50 \%$ of cells died following each of several paradigms, including incubation at $\mathrm{pH}_{e} 5.6$ for $2 \mathrm{hr}, \mathrm{pH}_{e} 6.1$ for $4 \mathrm{hr}$, and $\mathrm{pH}_{e} 6.4$ for $6 \mathrm{hr}$. Using DCF, it was found that a minor proton gradient was maintained at threshold $\mathrm{pH}_{e}\left(\mathrm{LD}_{s_{0}}\right)$ in both cell types (Table 1$)$.

No difference was observed in viability between solutions with or without lactate at extended exposure times (Table 1). Buffering of the acid solution with bicarbonate instead of HEPES did not affect cellular viability with long $(2 \mathrm{hr})$ exposure times (Table 2).

Figure 3. Long-term course of 10-min exposure to an HBS containing 20 mm sodium lactate titrated to various levels of pH. $A$, Control exposed to $\mathrm{pH}$ 7.3. $B$, Culture exposed to $\mathrm{pH} \mathrm{4.9.} \mathrm{Both} \mathrm{neurons} \mathrm{and} \mathrm{glial} \mathrm{cells} \mathrm{are} \mathrm{morphologically} \mathrm{indistinguishable} \mathrm{from} \mathrm{those} \mathrm{in} \mathrm{the} \mathrm{control} \mathrm{culture.} C$, Astrocytic process retraction, with membrane ruffling and substrate denudement after exposure to $\mathrm{pH} 4.5$. Some neurons show normal morphology, indicating a slightly higher tolerance toward acidity. $D$, Culture exposed to $\mathrm{pH} 3.9$. Very few cells, if any, remain viable. These phase-contrast photomicrographs were taken $24 \mathrm{hr}$ after acid exposure. Scale bar, $25 \mu \mathrm{m}$. 

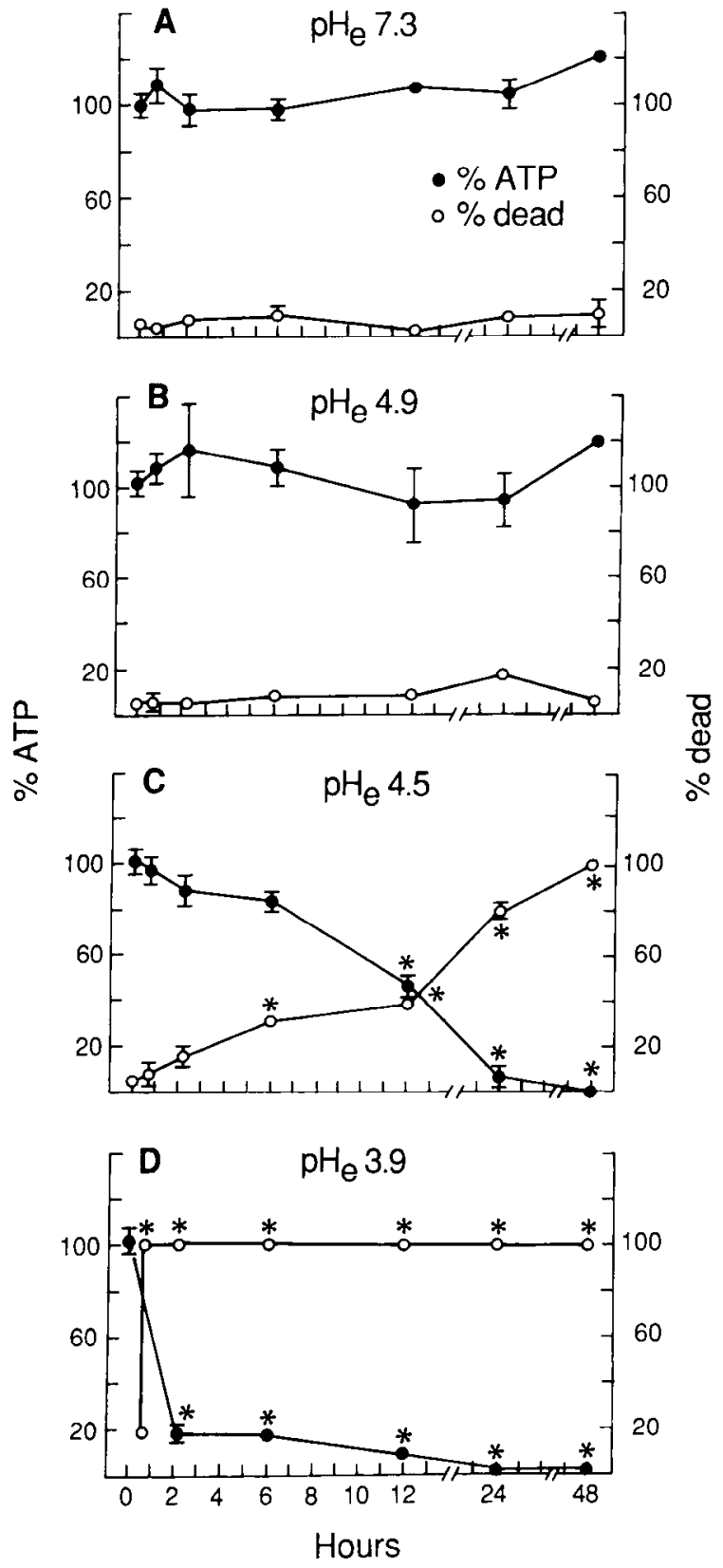

Figure 6. ATP content and death after 10-min exposure to $\mathrm{pH} 7.3$, $4.9,4.5$, and $3.9(A-D$, respectively). ATP content and viability remained normal after exposure to either $\mathrm{pH} 7.3$ or $\mathrm{pH} 4.9$. Fxposure to pH 4.5 triggered a process of delayed death, with ATP content and viability normal until $2 \mathrm{hr}$ after the exposure. First, after $6 \mathrm{hr}$, death increased to significant levcls as compared to control, whereas ATP content showed an insignificant decline at the same time point. Loss of viability progressed until the next day, when $100 \%$ of the cells were dead and ATP was unmeasurable. In contrast, loss of viability and ATP content occurred instantaneously after exposure to $\mathrm{pH} 3.9$. ANOVA was used to compare the groups, and Tukey's multiple comparison test was used to determine which groups were significantly different from control. Data points with asterisks were significantly different from control (culture at same time point exposed to $\mathrm{pH} 7.3$ for $10 \mathrm{~min}$ ), with $p$ $<0.05, n \geq 4$ for all values. ATP content is given in percent of control values obtained from sister cultures.

Temporal profile of viability and $A T P$ content. Figure $6 A-D$ illustrates those changes in cellular viability and ATP content occurring after 10-min exposures to varying degrees of lactic acidosis. ATP concentrations in normal cultures averaged 27.5

\begin{tabular}{llrr}
$\begin{array}{l}\text { Table 2. Influence of 2-hr exposure of lactate and } \mathrm{CO}_{2} \text { on cell } \\
\text { viability }\end{array}$ \\
& \multicolumn{3}{l}{ Percent dead } \\
\cline { 2 - 4 } Treatment & $\mathrm{pH}_{c}$ & \multicolumn{1}{l}{ With } & Without \\
\hline Lactate & 5.7 & $47 \pm 8(7)$ & $52 \pm 7(9)$ \\
$\mathrm{CO}_{2} / \mathrm{HCO}_{3}{ }^{-}$ & 7.3 & $3+4(4)$ & $5 \pm 5(4)$ \\
& 5.5 & $61 \pm 6(6)$ & $64 \pm 4(6)$ \\
& 7.3 & $5 \pm 3(4)$ & $4 \pm 2(4)$
\end{tabular}

Data are presented as mean $\pm \mathrm{SD}$; numbers in parentheses are number of observations.

${ }^{*} p<0.01$, paired $t$ test.

$\pm 4.9 \mu \mathrm{mol} / \mathrm{gm}$ protein $(n=65$; range, $16.8-38.1 \mu \mathrm{mol} / \mathrm{gm}$ protein). Baseline ATP content and viability were unchanged for $48 \mathrm{hr}$ following exposure to both $\mathrm{pH}_{e} 7.3$ and $\mathrm{pH}_{e} 4.9$ (Fig. $6 A, B)$. In contrast, ATP and cellular viability remained normal only initially following exposure to $\mathrm{pH} 4.5$. At $6 \mathrm{hr}$, an insignificant decrease of ATP was first evident, and viability was significantly $(p<0.05)$ diminished, with $31 \pm 4 \%(n=6)$ of the cells incorporating trypan blue (Fig. $6 \mathrm{C}$ ). By $12 \mathrm{hr}$ following exposure, significant drops were evident in both ATP levels and viability index; by $24 \mathrm{hr}, 80 \pm 10 \%(n=11)$ of the cells were dead, and ATP levels had fallen to $7 \pm 9 \%(n=4)$ of control values. By $48 \mathrm{hr}, 100 \%$ of the cells were dead, and ATP was unmeasurable (Fig. $6 \mathrm{C}$ ). Viability and ATP content were both lost when assessed $30 \mathrm{~min}$ after exposure to $\mathrm{pH}_{e} 3.9$ (Fig. $6 \mathrm{D}$ ).

Regulation of $\mathrm{pH}_{\mathrm{i}}$ in an acid environment. When $\mathrm{pH}_{r}$ was lowered from 7.3 to 6.8 (Table 3, Fig. $7 A-C$ ), all neurons regained normal $\mathrm{pH}_{i}$, while no glia did. Five of nine neurons initially acidified, but then slowly normalized for $\mathrm{pH}_{i}$ over the next 30-40 min, despite sustained extracellular acidification $(n$ $=9$; Fig. $7 B$ ). Four of nine neurons maintained normal $\mathrm{pH}_{i}$ during the lowering of $\mathrm{pH}_{e}$ to 6.8 (Table 3, Fig. $7 A$ ). In contrast, all glia $(n=7)$ acidified and showed little tendency towards normalization of $\mathrm{pH}_{i}$ during the 25 -min observation period (Fig. 7C). All neurons and glia alkalinized in a rebound fashion to levels higher than the initial $\mathbf{p H}_{i}$, once the $\mathrm{pH}_{e}$ was returned to 7.3 (Table 3).

The $\mathrm{pH}_{i}$ in both neurons and glia after prolonged exposures $(2,4$, and $6 \mathrm{hr})$ to toxic levels of acid, with or without lactate, was invariably slightly higher than $\mathrm{pH}_{e}($ Table 1$)$. Thus, the threshold for acid-induced death does not represent a discrete acid level at which $\mathrm{pH}_{i}$ homeostasis is suddenly lost in stepwise fashion. Acid-induced cell death is rather a function of both the time and the degree of intracellular acidification. Addition of $20 \mathrm{~mm}$ lactate to HBS did not cause a significant change in the degree of intracellular acidification at $2 \mathrm{hr}$ (Table 1).

Effects of incubation temperature. Matched series of lactic acid exposures were performed at $37^{\circ} \mathrm{C}$, including both 10 - and 120 min exposures to $\mathrm{LD}_{\mathrm{so}} \mathrm{pH}_{e}$. After acid exposure, one set of cultures from each series was maintained at $32^{\circ} \mathrm{C}$ for $4 \mathrm{hr}$ and at $37^{\circ} \mathrm{C}$ for the remaining $20 \mathrm{hr}$. The other set was kept at $37^{\circ} \mathrm{C}$ for the entire $24 \mathrm{hr}$. The 4-hr period of postacidification hypothermia improved cell viability after both short and long acid exposures (Table 4).

Sensitivity to acid as a function of cellular maturation. Cultures exposed to acid at various ages, ranging from 2 to 30 DIV, were equally vulnerable to acid exposure (Fig. 8). 

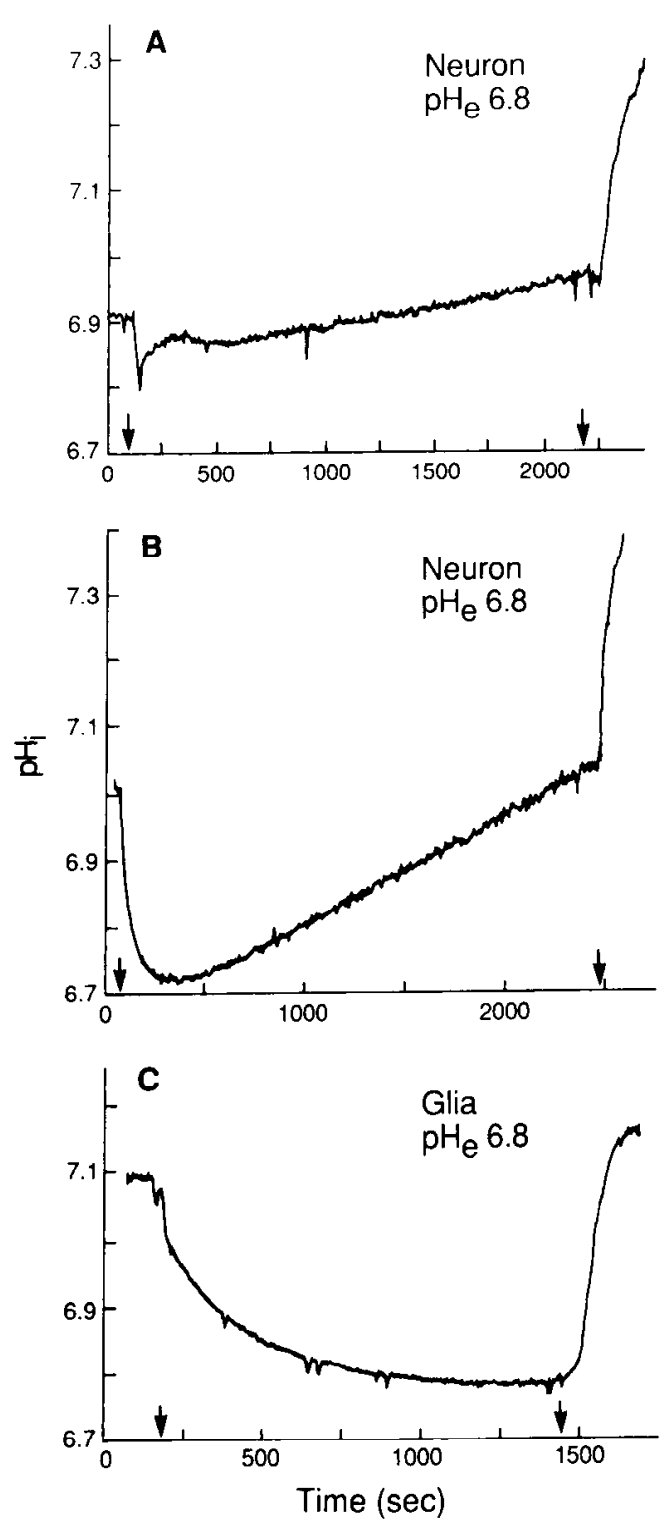

Figure 7. $\mathrm{pH}_{i}$ during exposure to $\mathrm{pH} 6.8$ in three representative cells.

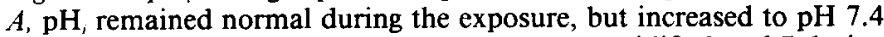
upon terminating the exposure (neuron). $B, \mathrm{pH}_{i}$ acidified to 6.7 during exposure to an $\mathrm{HBS}$ with $\mathrm{pH} 6.8$, but $\mathrm{pH}_{i}$ normalized within $1500 \mathrm{sec}$. An abrupt alkanization was evident when the acid exposure was terminated (neuron). $C$, This glial cell showed little tendency for $\mathrm{pH}_{i}$ normalization during the observation period. The cell alkanized upon returning to $\mathrm{pH}_{e}$.

\section{Discussion}

Traditionally, the homeostatic mechanisms subserving cellular $\mathrm{pH}_{i}$ have been thought of as tightly regulating $\mathrm{pH}_{i}$. The buffer capacity of brain cells is estimated at approximately $20 \mathrm{~mm}$

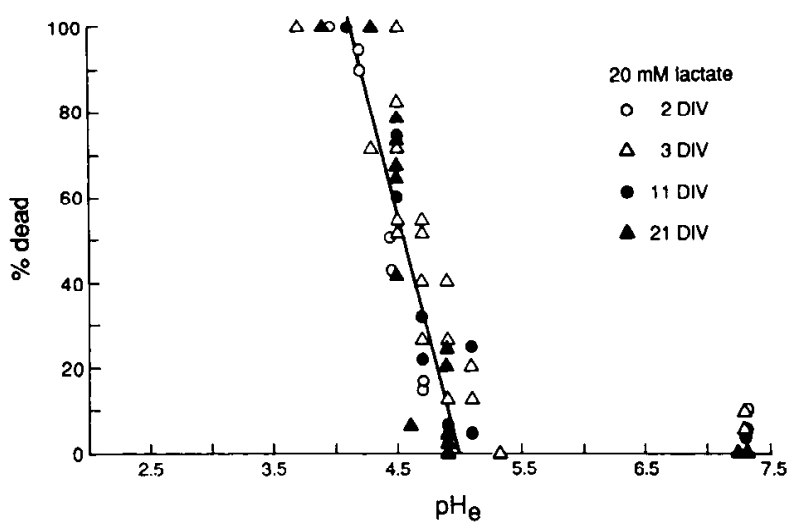

Figure 8. Determination of threshold for acid-induced cell death. Cultures at various DIV were exposed for 10 min each to an HBS titrated to the $\mathrm{pH}$ levels noted on the abscissa. Cellular death is indicated on the $y$-axis and is defined as the percentage of cells stained with trypan blue $24 \mathrm{hr}$ after exposure. There was no significant influence of DIV on the threshold for acid-induced death.

(Moody, 1984), with the result that approximately 20,000 protons are buffered for each free hydrogen ion appearing in the cytoplasm. In addition, such $\mathrm{pH}$ regulators as the proton/hydrogen exchanger are effective proton extruders; proton transport rates increase exponentially with the degree of intracellular acidification (Moolenaar, 1986). Nevertheless, when the proton influx exceeds the cellular capacity for buffering and proton extrusion, net intracellular acidification occurs. The present study indicates that the $\mathrm{pH}_{i}$ homeostatic mechanisms are readily overwhelmed in neurons, and even more so in astrocytes during exposure to extracellular acidosis. $\mathrm{pH}_{i}$ always fell significantly at $\mathrm{pH}_{e}$ lower than 6.8. Furthermore, this study demonstrates that the threshold for acid-induced death in both cell types does not represent a fixed level of acidosis at which $\mathrm{pH}_{i}$ homeostasis is lost in stepwise fashion; cell death is rather a combinatorial function of both the time and the degree of intracellular acidification, such that $\mathrm{LD}_{50}$ increases from $\mathrm{pH}_{i} 3.5$ for 10 -min exposures to $\mathrm{pH}_{i} 6.5$ after 6 -hr acid exposures.

Local accumulation of lactic acid has been implicated in the development of ischemic tissue damage (Plum, 1983). This study demonstrated that a degree of intracellular acidity, spanning the range of $\mathrm{pH}_{i} 5.5-6.5$, which is achieved during in vivo normoglycemic-ischemia (Smith et al., 1986), kills both neurons and glia after 2-6 hr incubation in vitro. Intracellular acidosis may therefore be deleterious to cells during focal ischemia, in which the intracellular hydrogen ion concentration is elevated for hours (Nedergaard et al., 1990). We have no evidence suggesting that lactate in itself is harmful. Control cultures exposed to $20 \mathrm{~mm}$ lactate at normal $\mathrm{pH}_{e}$ for up to $6 \mathrm{hr}$ were undamaged. Rather, the rapid intracellular acidification obtained with lactate-containing solutions, as compared to $\mathrm{HCl}$-titrated HEPES buffer,

Table 3. Changes in $\mathrm{pH}_{i}$ during exposure to $\mathrm{pH}_{\epsilon} 6.8$

\begin{tabular}{llllll} 
& \multicolumn{2}{l}{} & & \\
\cline { 2 - 5 } & Baseline & Decline & Recovery & Final & Time (sec) \\
\hline Neuron $(\mathrm{n}=9)$ & $6.95 \pm 0.12$ & $6.80 \pm 0.15$ & $6.94 \pm 0.12$ & $7.26 \pm 0.14$ & $1625 \pm 663$ \\
Neuron $^{a}(\mathrm{n}=4)$ & $6.89 \pm 0.10$ & - & - & $7.16 \pm 0.08$ & - \\
Glial cell $(\mathrm{n}=7)$ & $7.09 \pm 0.09$ & $6.78 \pm 0.08$ & $6.82 \pm 0.09$ & $7.15 \pm 0.18$ & $1551 \pm 203$
\end{tabular}




\section{Table 4. Effect of incubation temperature after acid exposure}

\begin{tabular}{llcc}
\multirow{2}{*}{$\begin{array}{l}\text { Exposure } \\
\text { time }\end{array}$} & $\mathrm{pH}_{e}$ & $32^{\circ} \mathrm{C}$ & $37^{\circ} \mathrm{C}$ \\
\hline $10 \mathrm{~min}$ & 4.4 & $46 \pm 11(10)$ & $99 \pm 3^{*}(7)$ \\
& 4.6 & $23 \pm 5(5)$ & $57 \pm 7^{*}(5)$ \\
& 7.3 & $6 \pm 4(8)$ & $4 \pm 3 \quad(8)$ \\
$2 \mathrm{hr}$ & 5.6 & $9 \pm 4(4)$ & $46 \pm 6^{*}(4)$ \\
& 5.8 & $7 \pm 5(6)$ & $31 \pm 10^{*}(6)$ \\
& 7.3 & $1 \pm 2(3)$ & $4 \pm 3 \quad(4)$
\end{tabular}

Data are presented as mean \pm SD; numbers in parentheses are number of observations. All solutions contained $20 \mathrm{~mm}$ sodium lactate.

$* p<0.01$, paired $t$ test.

might explain why the $\mathrm{pH}_{e} \mathrm{LD}_{50}$ rose form 3.3 to 4.6 for 10 min exposures in the presence of lactate. The combination of hypoxia and acidosis has recently been shown to lower further the $\mathrm{pH}$ threshold for irreversible injury (Tombaugh and Sapolsky, 1990). Thus, acidosis might also play a role in injury associated with relatively brief episodes of transient global ischemia. Interestingly, moderate acidosis decreases glutamate neurotoxicity in cultures, presumably through a reduction in the NMDA-associated channel conductance (Tang et al., 1988; Giffard et al., 1990).

Cellular vulnerability to intracellular acidification presumably is a product of the many cellular processes sensitive to changes in $\mathrm{pH}_{i}$. Glycolysis, protein synthesis, $\mathrm{Ca}^{2+}$ buffering, adenylate cyclase activity, and mitosis have all been shown to be exquisitely sensitive to pH (Busa and Nuccitelli, 1984). In addition, severe acidosis causes protein denaturation: the excess of intracellular protons binds to available negative groups on proteins, especially the imidazole moiety of histidine (Tanford, 1968). The resulting structural instability of the proteins and concurrent alteration of covalent bonds cause irreversible denaturation (Tanford, 1968). Available data indicate that cellular proteins vary considerably in their stability at low $\mathrm{pH}$. Some proteins, such as lysozyme, retain their native conformation below pH 2, while others such as glyceraldehyde-3-phosphate unfold below $\mathrm{pH} 4$, irreversibly losing their enzymatic activity (Tanford, 1968).

We observed two patterns of cellular death. Exposure to moderate levels of acidity induced a process of cell injury with long latency. The dying cells excluded trypan blue for several hours after the exposure, and their ATP level remained normal during this period. Nevertheless, this population of cells began to lose viability after 6-24 hr, such that within $48 \mathrm{hr}$ following acid exposure, all cells incorporated trypan blue and lost their intracellular ATP stores. During this period, viability loss and ATP decline occurred in parallel. This delayed process of cell injury contrasted with that in cells exposed to highly acidic solutions, in which all cells died within $30 \mathrm{~min}$ after the exposure. This rapid loss of viability and ATP content following exposure to low $\mathrm{pH}$ suggests direct disruption of the cell membrane. Lipid components of the plasma membrane might be expected to be very resistant to low $\mathrm{pH}$ : models of planar lipid bilayers, such as the lecithin-cholesterol membrane and phospholipid bilayers, resist exposure below $\mathrm{pH} 2$ without conformational changes (Ohki and Goldup, 1969; Gutknecht, 1987). Most likely, the denaturation of structural and integral proteins under these highly acidic conditions might cause secondary disruption of and leakage through the plasma membrane.
The mechanism behind the slow process of cell death is unknown. Membrane disruption, energy depletion, and metabolic derangement are all likely participants. In addition, irreversible denaturation of a cohort of key regulatory proteins, in combination with a failure in protein synthesis, might even prematurely trigger a genetically predetermined process of programmed cell death. The present study demonstrates that slow cell death can be initiated in vitro, and that this process can occur in glial cells as well as neurons. Both the time course and the outcome of cell injury could be experimentally manipulated: postinjury incubation hypothermia improved cellular viability to a significant degree. This hypothermic rescuc of acid-cxposed cells suggests that a temperature-dependent metabolic slowing may allow the cells to survive an initial critical period, following which recovery becomes possible.

Cultures only a few days in vitro were composed of more than $95 \%$ neuronal cells as determined by double immunocytochemistry for MAP-2 and GFAP, whereas older cultures contained successively greater proportions of glial cells. We did not maintain enriched neuronal cultures by addition of mitotic inhibitors, because such treatment might have conceivably changed the threshold for acid-induced death. We made no direct effort to assess the differential sensitivities of neurons and glia to acidosis in these experiments. Nevertheless, during microscopic examinations of the acid-exposed cultures, it was often noted that neurons appeared to be more tolerant than glial cells to threshold acid exposures (Fig. 1). However, three lines of evidence indicate that such differential sensitivitics arc minimal. First, acid exposure performed on cultures from 2 to 21 DIV revealed the same $\mathrm{LD}_{\text {so }}$ at all maturational ages in vitro (Fig. 8). Second, the regression line for acid-induced death was steep and linear; the absence of plateau values suggests uniform susceptibility. Third, $\mathrm{pH}_{i}$ declined to the same level during extracellular acidification in neurons and glial cells. Thus, though the precise threshold for acid-induced death appears to differ somewhat between neurons and glial cells (Goldman et al., 1989), it is likely that intracellular acidosis disrupts basic mechanisms common to all brain cells in an analogous fashion.

In summary, we have shown that acid-induced neurotoxicity is a product of both the degree and the duration of intracellular acidity, that exposure to moderate acidity triggers death in some cells with a latency of as long as $24-48 \mathrm{hr}$, and that delayed lethal injury may be attenuated by postinjury hypothermia.

\section{References}

Busa WB, Nuccitelli R (1984) Metabolic regulation via intracellular pH. Am J Physiol 246:R409-R438.

Chaillet JR, Boron WF (1985) Intracellular calibration of a pH-sensitive dye in isolated, perfused salamander proximal tubules. J Gen Physiol 86:325-345.

Choi DW (1987) Ionic dependence of glutamate neurotoxicity. J Neurosci 7:369-379.

Connor JA, Tseng H-Y, Hockberger PE (1987) Depolarization- and transmitter-induced changes in intracellular $\mathrm{Ca}^{++}$of rat cerebellar granule cells in explant cultures. J Neurosci 7:1384-1400.

Giffard R, Mongen H, Chritine C, Choi D (1990) Acidosis reduces NMDA receptor activation, glutamate neurotoxicity, and oxygenglucose deprivation neuronal injury in cortical cultures. Brain Res 506:339-342.

Goldman SA, Pulsinelli WA, Clarke WY, Kraig RP, Plum F (1989) The effects of extracellular acidosis on neurons and glia in vitro. $\mathrm{J}$ Cereb Blood Flow Metab 9:471-477.

Gutknecht J (1987) Proton/hydroxide conductance and permeability through phospholipid bilayer membranes. Proc Natl Acad Sci USA 84:6443-6446. 
Kobatake K, Sako K, Izawa M, Yamamoto YL, Hakim AM (1984) Autoradiographic determination of brain $\mathrm{pH}$ following middle cerebral artery occlusion in the rat. Stroke 15:540-547.

Kraig KP, Chesler M (1990) Astrocytic acidosis in hyperglycemic and complete ischemia. J Cereb Blood Flow Metab 10:104-114.

Kraig RP, Petito C, Plum F, Pulsinelli WA (1987) Hydrogen ions kill brain at concentration reached in ischemia. J Cereb Blood Flow Metab 7:379-386.

Lowry OH, Passonneau JV (1972) A flexible system of enzymatic analysis. New York: Academic.

Meyer RE, Yamaguchi S (1977) Nervous system effects of cardiac arrest in monkeys. Arch Neurol 34:65-74.

Moody W (1984) Effects of intracellular $\mathrm{H}^{+}$on the electrical properties of excitable cells. Annu Rev Neurosci 7:257-278.

Moolenaar WH (1986) Regulation of cytoplasmatic $\mathrm{pH}$ by a $\mathrm{Na}^{+} / \mathrm{H}^{+}$ exchange. Trends Biol Sci 2:141-143.

Nedergaard M (1987) Transient focal ischemia in hyperglycemic rats is associated with increased cerebral infarction. Brain Res 408:7985 .

Nedergaard M, Desai S, Pulsinelli WA (1990) Dicarboxy-dichlorofluorescein: a new fluorescent probe for measuring acidic pH. Anal Biochem 187:109-114.

Nedergaard M, Kraig RP, Tanabe J, Pulsinelli WA (1991) Dynamics of intracellular and extracellular $\mathrm{pH}$ in the evolving infarct. Am J Physiol 260:R581-R588.

Norenberg MD, Mozes LW, Gregorios JB, Norenberg LB (1987) Effects of lactic acid on astrocytes in primary culture. J Neuropathol Exp Neurol 46:154-166.

Ohki S, Goldup A (1968) Influence of $\mathrm{pH}$, sodium and calcium ions on the D.C. resistance of black egg lecithin-cholesterol films. Nature $217: 458-459$.
Phillips HJ (1973) Dye exclusion tests for cell viability. In: Tissue culture methods and applications (Kruse PP, Patterson MK, eds), pp 406-408. New York: Academic.

Pulsinelli WA, Waldman D, Rawlinson D, Plum F (1982) Moderate hyperglycemia augments ischemic brain damage: a neuropathologic study in the rat. Neurology 32:1239-1246.

Rink TJ, Tsien RY, Pozzan T (1982) Cytoplasmatic pH and free $\mathrm{Mg}^{++}$ in lymphocytes. J Cell Biol 95:189-196.

Roos A, Boron WF (1981) Intracellular pH. Physiol Rev 61:297-434.

Schnaar RL, Weigel PH, Kuhlenschmidt MS, Lee YC, Roseman S (1987) Adhesion of chicken hepatocytes to polyacrylamide gels derivatized with $N$-acetylglucosamine. J Biol Chem 253:7940-7951.

Siemkowitz E, Hansen AJ (1978) Clinical restitution following cerebral ischemia in hypo-, normo, and hyperglycemic rats. Acta Neurol Scand $58: 1-8$.

Smith M-L, von Hanwehr R, Siesjo BK (1986) Changes in extra- and intracellular $\mathrm{pH}$ in the brain during and following ischemia in hyperglycemic and in moderately hypoglycemic rats. J Cereb Blood Flow Metab 6:574-583.

Tanford C (1968) Protein denaturation. In: Advances in protein chemistry, Vol 23 (Anfinsen CB, Anson ML, Edsall JT, Richards FM, eds), pp 121-275. New York: Academic.

Tang CM, Dichter M, Morad M (1988) Mechanism of NMDA channel modulation by $\mathrm{H}^{+}$at near physiological $\mathrm{pH}$. Soc Neurosci Abstr 15: 326.

Thomas JA (1986) Intracellular trapped $\mathrm{pH}$ indicators. In: Optical methods in cell physiology (Thomas JA, ed), p 311. New York: Wiley.

Tombaugh GC, Sapolsky RM (1990) Mechanistic distinctions between excitotoxic and acidotic hippocampal damage in an in vitro model of ischemia. J Cereb Blood Flow Metab 10:527-535. 